\title{
Production, Phytochemical Characterization and Acceptability of Wines from Green Seaweeds (Halimeda macroloba, Caulerpa sertularioides and Caulerpa racemosa)
}

\author{
Hilario S. Taberna Jr. ${ }^{1}$; Aaron Paul P. Puljanan ${ }^{2 *}$; Ruperta D. Cezar²; Noel S. \\ Quidato $^{2}$
}

${ }^{1}$ Iloilo Science and Technology University, Iloilo City Campus, LaPaz, Iloilo City, Philippines

${ }^{2}$ Iloilo Science and Technology University, Dumangas Campus, Dumangas, Iloilo, Philippines

*Corresponding author. Email: Puljananaaronpaul@yahoo.com

\begin{abstract}
Seaweeds are tagged as the medical food of the 21 st century due to its being rich in bioactive substances, minerals and vitamins. Seaweeds could be processed as wine and could be used as a medicine or a delicacy. The bioactive substances inherent to the seaweed and responsible for its various medicinal properties could be made available during the fermentation process. In this study, wines were produced from three (3) green seaweed species, namely: Halimeda macroloba, Caulerpa sertularioides and Caulerpa racemosa using three (3) kinds of sugar, characterized by its phytochemical profile, total phenolic content (TPC), total flavonoid content (TFC) and total antioxidant activity (TAA), and subjected to sensory evaluation for acceptability. Results show that wines produced from green seaweeds are rich in flavonoids, terpenoids, coumarin and betacyanin. TPC of wines ranged from 54 - $467 \mathrm{mg}$ Gallic Acid Equivalent (GAE)/L. TFC ranged from 7 - 356 mg Cathechin Equivalent (CE)/L. TAA ranged from 97 - 558 mg Ascorbic Acid Equivalent (AAE)/L. In general, wines fermented using muscovado sugar have the highest TPC, TFC and TAA values. The general acceptability of seaweeds wines using a 5-point rating scale ranged from "liked moderately" to "liked very much".
\end{abstract}

Keywords: Green seaweed wine, phytochemical profile, total antioxidant activity.

\section{INTRODUCTION}

The term "Seaweed" refers to a diverse group of macrobenthic and photosynthetic plants found in the near-shore marine environment (https://www.biologyonline.com/dictionary/seaweed-

$\underline{\mathrm{d} 3}$ ). Seaweeds are classified into three major taxa based on their pigmentation [1]: Chlorophyceae (green seaweeds), Phaeophyta (brown seaweeds) and Rhodophyta (red seaweeds).

In Panay Island, Western Visayas, Philippines, a total of 112 seaweed species were identified [2]. Forty-one (41) of which belong to the green seaweeds, 20 species of brown and 51 species of red. Most of these seaweeds were used as human food, as animal feed, source of agar (red seaweeds), source of algin, simple sugars and sugar alcohol (brown seaweeds) and source of pigments. Some were used as medicines (Caulerpa spp., Gracilaria spp., Acanthopora spp., Dictyota spp.). Seaweeds are utilized in the food industry, pharmacy and medicine, thus, are considered of significant economic importance [3]. In fact, seaweeds are tagged as the medical food of the $21 \mathrm{st}$ century due to its being rich in minerals, vitamins, trace elements and bioactive substances [4].

Caulerpa species, commonly known as seagrapes, are widely harvested and consumed in the Philippines [5]. Sea grapes are regarded as an economically important commodity and are abundant during the months of January to April [6]. Magdugo et al. [7] reported that Caulerpa racemosa have high amounts of proteins and the essential amino acids present were comparable to FAO/WHO requirements. Caulerpa species were found to be rich in essential minerals and trace elements $[2,8]$, exhibited promising antioxidant, reducing and 
antidiabetic activities [8], showed immunostimulatory activities $[9,10]$ and displayed potent antimicrobial activity and anti-inflammatory activity [11, 12].

Unlike the Caulerpa species, Halimeda macroloba is not utilized commercially although it was reported to contain growth regulators such as auxin, gibberellin and cytokinin [2]. Various studies have reported that Halimeda macroloba has a great potential as new antioxidant sources for human health [13, 14, 15] and also exhibited broad spectrum of antibacterial and antifungal activity $[16,17]$.

Seaweeds could be processed as wine and could be used as a medicine or a delicacy. In 2006, seaweed wine has hit the German market picking a price of US\$28 a bottle

(http://www.dw.com/en/seaweedwinehitsgermanysstore s/a1993083). The bioactive substances inherent to the seaweed and responsible for its various medicinal properties could be made available during the fermentation process. During fermentation, these bioactive compounds are released into wine (aqueous ethanolic solution) making the polyphenols and bioactive components exposed, thereby increasing their bioavailability and free during their absorption [18]. According to Morina and Kongoli [19], wines rich in phenolic compounds were found to have powerful antioxidant activity. Antioxidants play a crucial role in the prevention of many diseases such as cancer, inhibiting tumor initiation and heart diseases. Furthermore, they reported that phenolic compounds play an important role in several sensory properties of wine such as color, flavor, astringency and hardness.

The production and characterization of wines from seaweeds collected in the Philippines has been reported. Lazado (2007, Unpublished Thesis) studied the physicochemical properties and sensory attributes of wine produced from seaweed Gracilaria verrucosa. Wine was also being produced from sea grapes (Caulerpa sp.) (Intellectual Property Philippines Application Number 2/2017/000905) and from sea lettuce (Ulva sp.) (Intellectual Property Philippines Application Number $2 / 2018 / 000935$ ). However, none of these studies reported on the phytochemical composition and antioxidant activity of the seaweed wines produced in which people are after for in drinking wines.

In view of this, a research project was initiated to investigate the suitability of pureed green seaweeds for wine production, and also to characterize the wine produced in terms of phytochemical composition and antioxidant activity. It had three objectives, namely: (1) to determine the right formulation for wine making with green seaweeds as raw material; (2) to quantify the phytochemicals present in produced wines and its antioxidant activity; and (3) to determine the acceptability of the produced wines. The laboratory experimental results obtained are presented in this paper.

\section{METHODOLOGY}

\subsection{Collection of Seaweed Sample}

The seaweed samples, except for Caulerpa racemosa, were collected at the coastal area of San Dionisio, in Northern Iloilo, Philippines. Seaweed samples were collected manually or by the use of scissor or knife. Each seaweed species was placed in a net bag, cleaned with seawater to remove extraneous materials and brought to the processing area. Upon arrival in the processing area, the seaweed samples were again cleaned with foreign materials, thoroughly washed with tap water until the final washing was clear and finally with distilled water. Samples of Caulerpa racemosa were purchased at a public market in Northern Iloilo. A representative sample of each species was set aside for preservation, identification and documentation. The seaweed samples were identified up to the species level based on the book of Hurtado et al. [2] and were confirmed by the Farming Systems and Aquatic Ecology Section, Aquaculture Department, Southeast Asian Fisheries Development Center in Tigbauan, Iloilo.

\subsection{Wine Making/Fermentation}

One kilogram of cleaned seaweed samples were homogenized separately using a blender machine to make a puree. Several treatments were conducted using different kinds of sugar. Sugar syrup was added to the seaweed puree solution until the brix content of $22 \%$ was reached. The mixture was heated to $60^{\circ} \mathrm{C}-80^{\circ} \mathrm{C}$, cooled to $40^{\circ} \mathrm{C}$ and added with yeast. The seaweed-sugar-yeast solution was allowed to ferment until the sugar content of the liquid was $\leqslant 10 \%$. The wine produced after about 4 weeks of fermentation was transferred into a large bottle for settling. The clear wine was decanted, bottled and stored away from direct sunlight.

\subsection{Phytochemical Screening of Seaweed Extract}

Sub-samples of pureed seaweeds were soaked in ethanol for $48 \mathrm{hrs}$ and the extracts were concentrated using rotary evaporator. The concentrated extract was subjected to qualitative phytochemical analysis along with the seaweed wines produced following the procedure described by Guevara [20] and Sivagnanavelmurugan [21].

\subsection{Determination of Total Phenol Content}

The total phenol content of the seaweed wines was determined according to the method described by Waterhouse [22] using Gallic acid as a calibration standard. The color intensity was measured spectrophotometrically at $765 \mathrm{~nm}$ after the reaction with Folin-Ciocalteau phenol reagent. Results are expressed 
as Gallic acid equivalents (GAE, mg/L). All measurements were performed in triplicate.

\subsection{Determination of Total Flavonoids}

The total flavonoid content in seaweed wine samples was determined spectrophotometrically using the aluminum chloride assay [23]. The absorbance was measured at $510 \mathrm{~nm}$ and the concentration was expressed as catechin equivalent $(\mathrm{CE}, \mathrm{mg} / \mathrm{L})$. The result in every assay was obtained from three parallel determinations.

\subsection{Determination of Total Antioxidant Activity}

The phosphomolybdate assay described by Prieto et al. [24] was modified and used to determine the total antioxidant activity (TAA) of the seaweed wines produced. In summary, $1 \mathrm{~mL}$ of molybdate reagent solution was added to $10 \mu \mathrm{L}$ of wine samples. The vials were capped and incubated in a water bath at $95^{\circ} \mathrm{C}$ for 90 min. The sample mixture was cooled to room temperature, and the absorbance was measured at $695 \mathrm{~nm}$ against a blank. Ascorbic acid was used to prepare a standard curve in the range $20-100 \mathrm{mg} / \mathrm{L}$, and the total antioxidant activity was expressed in terms of milligram per liter ascorbic acid equivalent (AAE, mg/L). All measurements were triplicated.

\subsection{Sensory Evaluation}

All produced wines were subjected to sensory evaluation based on the method described by Roldan \& Edica [25].

\section{RESULTS AND DISCUSSION}

\subsection{Seaweed Samples}

Three (3) green seaweed species were collected namely: Halimeda macroloba Decaisne, Caulerpa sertularioides (S.G. Gmelin) Howe and Caulerpa racemosa var. laetevirens (Montagne) Weber-van Bosse.

The seaweeds collected were abundant in the coastal areas of San Dionisio, Iloilo and in Estancia, Iloilo and of no economic importance to the community except for Caulerpa racemosa in which it is sold in the market for food as simple salad. Hurtado et al. [2] reported that Caulerpa species were used as human food, are source of amino acids, fatty acids, lipids and minerals. They are also found to lower blood pressure aside from having an antifungal property. On the other hand, Halimeda macroloba was reported to contain growth regulators such as auxin, gibberellin and cytokinin [2].

\subsection{Wine Characteristics}

Table 1 shows the physico-chemical characteristics of wines produced from green seaweeds. Wine color is affected by the sugar used during fermentation. The use of muscovado sugar resulted to a yellowish-dark brown wines, while the refined and washed sugars resulted to light yellow-colored wines. The $\mathrm{pH}$ values of wines produced ranged from $3.2-3.8$ and the total acidity ranged from 0.097 - $1.034 \mathrm{~g}$ Tartaric Acid (TA)/ $100 \mathrm{~mL}$. Sugar content after fermentation ranged from $3.0-4.0$ ${ }^{\circ}$ Brix while the alcohol content of the wines produced ranged from $11.8-12.2 \%$.

Table 1. Physico-chemical characteristics of green seaweeds wines.

\begin{tabular}{|c|c|c|c|c|}
\hline Wine & Physical Appearance & $\mathrm{pH}$ & $\begin{array}{l}\text { Titrable Acidity } \\
\text { (g TA } 100 \mathrm{~mL} \text { ) }\end{array}$ & $\begin{array}{c}\% \\
\text { Alcohol }\end{array}$ \\
\hline GS1-R & Faint yellow, clear & 3.4 & 1.034 & 12.1 \\
\hline GS1-W & Faint yellow, clear & 3.8 & 0.766 & 12.0 \\
\hline GS1-M & Yellowish dark brown, turbid & 3.6 & 0.779 & 12.0 \\
\hline$G S 2-R$ & Faint yellow, clear & 3.2 & 0.378 & 11.9 \\
\hline GS2-W & Faint yellow, clear & 3.3 & 0.323 & 12.1 \\
\hline$G S 2-M$ & Yellowish dark brown, turbid & 3.3 & 0.401 & 12.0 \\
\hline GS3-R & Faint yellow, clear & 3.6 & 0.165 & 11.8 \\
\hline GS3-W & Faint yellow, clear & 3.7 & 0.097 & 11.9 \\
\hline GS3-M & Yellowish dark brown, turbid & 3.3 & 0.533 & 12.2 \\
\hline
\end{tabular}

The $\mathrm{pH}$ of a wine is a measure of the strength and concentration of the dissociated acids present in the said medium. It plays a vital role in winemaking process. $\mathrm{pH}$ influences wine's microbiological stability, affects the equilibrium of tartrate salts, influences the solubility of proteins and ability to clarify, influences sensory attributes and affects color and oxidative and browning reactions [26, 27, 28]. A pH between 3.0 and 4.0 is optimal for most wines [26]. For grape wines, white wines may have $\mathrm{pH}$ values of 3.5 or lower while red wines may have higher values [27]. The $\mathrm{pH}$ of the seaweed wines produced are within the reported optimum $\mathrm{pH}$ values for most wines.

Titratable acidity (TA) is a measure of the total amount of hydrogen ions or the acid content of wine. TA is usually reported in units of tartaric acid, malic acid, or citric acid depending on the nature of fruit or plant material. TA analysis is one of the most basic analyses in a winery lab because fruits and other possible plant wine materials contain significant amounts of organic acids. The acid content impacts the taste, color, and microbial stability of the wine. Some regulatory bodies prescribe a minimum TA (like 0.45 grams tartaric $/ 100 \mathrm{~mL}$ for red wine in the EU). A general range for TA in red wine is 0.6 to 0.8 , for red wine must it is 0.7 to 0.9 (chateauhetsakais.com/total-acidity; Accessed date: April 11, 2019). The seaweed wines produced using the muscovado sugar have TA values within the reported prescribed TA for red wine. Generally, seaweed wines 
produced using refined and washed sugars have lower TA values $(0.097-0.407 \mathrm{~g} / 100 \mathrm{~mL})$ except for Halimeda wines with TA values of $1.034 \mathrm{~g} / 100 \mathrm{~mL}$ and $0.766 \mathrm{~g} / 100 \mathrm{~mL}$, respectively. The increase in TA values could be attributed to the seaweed sample itself wherein continues fermentation of wine occurs. Other possible reasons could be the high acetic acid concentration due to oxidation and the formation of Succinic acid as a byproduct of alcoholic fermentation [29].

There is no direct or predictable relationship between $\mathrm{pH}$ and TA, and the same titratable acidity can be measured in different wines with either low $\mathrm{pH}$ or high $\mathrm{pH}$. The $\mathrm{pH}$ is not correlated with the concentration of acids present, but is influenced by their ability to dissociate (The Australian Wine Research Institute, Accessed Date: April 10, 2019; https://www.awri.com.au/industry support/winemaking _resources/frequently_asked_questions/acidity_and_ph/ ) .

\subsection{Phytochemical Profiles of Seaweed Ethanolic Extracts and Wines}

The concentrated ethanolic extracts of seaweed samples were subjected to phytochemical screening for the presence of alkaloids, tannins, anthraquinones, glycosides, reducing sugar, saponins, flavonoids, phlobatanins, steroids, terpenoids, coumarin, emodins, anthocyanin and betacyaninas chemical constituents. The detailed results of all tests for phytochemical screening of each species are summarized in Table 2.

Table 2. Phytochemical constituents of seaweed ethanolic extracts.

\begin{tabular}{|c|c|c|c|}
\hline \multirow{2}{*}{$\begin{array}{l}\text { Phytochemical } \\
\text { Constituent }\end{array}$} & \multicolumn{3}{|c|}{ Seaweed E thanolic Extract } \\
\hline & GS1 & GS2 & GS3 \\
\hline Alkaloids & - & - & - \\
\hline Tannins & - & - & - \\
\hline Anthraquinones & - & - & - \\
\hline Glycosides & - & - & - \\
\hline Reducing Sugar & - & - & - \\
\hline Saponins & - & - & - \\
\hline Flavonoids & - & - & - \\
\hline Phlobatanins & - & - & - \\
\hline Steroids & - & - & - \\
\hline Terpenoids & + & + & + \\
\hline Coumarin & + & + & + \\
\hline Emodins & - & - & - \\
\hline Anthocyanin & - & - & - \\
\hline Betacyanin & + & + & + \\
\hline
\end{tabular}

Terpenoids, coumarin and betacyanin are common in all seaweed species studied. Terpenoids were reported to be present in Caulerpa sp. [30]. Coumarin have been characterized in green seaweeds by Perez-Rodriguez et al. [31] as reported by Stengel et al. [32]. Rajasekar et al. [33] reported that betacyanin was found to be present in green seaweeds. Other studies $[34,35,36]$ found that $C$. racemosa possess alkaloids, flavonoids, glycosides, phenols, saponins and steroids, however, these secondary metabolites were not detected qualitatively in the ethanolic extract of our samples. The differences in results could be attributed to some factors like climatic condition, season, species, subspecies, harvest and the method used for extraction of compounds which greatly affects the chemical compositions of the extract [37]

Phytochemical screening of the generated seaweed wines was also conducted after fermentation. Results are presented in Tables 3. In general, the phytochemicals present in seaweeds are not retained in wines except for flavonoids, terpenoids, coumarin and betacyanin. Some phytochemicals were lost during the fermentation process and some were enhanced. The detection of chemical constituent not present in the ethanolic extract of the seaweed itself could be attributed to sugar used or to the fermentation process itself. Rathi [38] reported that during fermentation, bioactive compounds are released into wine (aqueous ethanolic solution) making the polyphenols and bioactive components exposed, thereby increasing their bioavailability.

Table 3. Phytochemical constituents of green seaweeds wines.

\begin{tabular}{|c|c|c|c|c|c|c|c|c|c|}
\hline \multirow{3}{*}{$\begin{array}{c}\text { Phytochemical } \\
\text { Constituent }\end{array}$} & \multicolumn{9}{|c|}{ Seaweed Wine } \\
\hline & GS1 & GS1 & GS1 & GS2 & GS2 & GS2 & GS3 & GS3 & GS3 \\
\hline & $-R$ & $-W$ & -11 & $-R$ & $-W$ & -11 & $-R$ & $-W$ & -11 \\
\hline Alkaloids & - & - & - & - & - & - & - & - & - \\
\hline Tannins & - & - & - & - & - & - & - & - & - \\
\hline Anthraquinones & - & - & - & - & - & - & - & - & - \\
\hline Glycosides & - & - & - & - & - & - & - & - & - \\
\hline Reducing Sugar & - & - & - & - & - & - & - & - & - \\
\hline Saponins & - & - & - & - & - & + & + & - & - \\
\hline Flavonoids & + & + & + & + & + & + & + & + & + \\
\hline Phlobatanins & - & - & - & - & - & - & - & - & - \\
\hline Steroids & - & - & - & - & - & - & - & - & - \\
\hline Terpenoids & + & + & + & + & + & + & + & + & + \\
\hline Coumarin & + & + & + & + & + & + & - & + & - \\
\hline Emodins & - & - & - & - & - & - & - & - & - \\
\hline Antho cyanin & - & - & - & - & - & - & - & - & - \\
\hline Betacyanin & + & + & + & + & + & + & + & + & + \\
\hline
\end{tabular}

The phytochemical constituent flavonoids which are not detected in the ethanolic extracts of green seaweed samples were found present in the fermented solutions. Terpenoids, as well as the coumarins and betacyanins were retained in wines (Table 3 ) regardless of the sugar solution used.

The study of phytochemicals present in wines are essential. Phytochemicals have antioxidant or hormonelike effect which helps to fight against diseases like 
cancer, heart disease, diabetes, high blood pressure and preventing the formation of carcinogens on their target tissues [39].

\subsection{Total Phenolic Content}

The total phenolic content (TPC) of wines produced were determined quantitatively and the results are shown in Figure 1. TPC is expressed as milligram Gallic acid equivalent per liter (mg GAE/L). Phenolic compounds play an important role in several sensory properties of wine such as color, flavor, astringency and hardness [19].

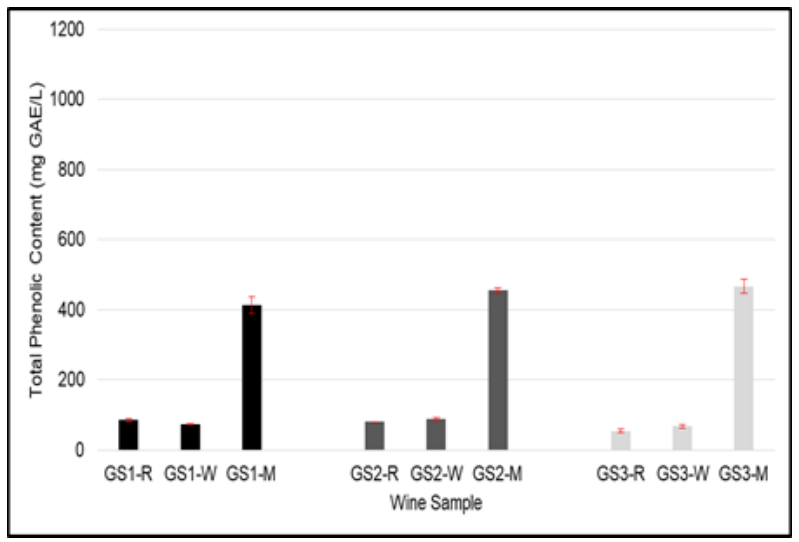

Figure 1. Total phenolic content of wines generated from fermentation of three (3) green seaweed species. Results are expressed as mean of three (3) replicates \pm standard deviation which is indicated by an error bar.

The TPC value of the green seaweed wines is $54-$ $467 \mathrm{mg}$ GAE/L. In general, seaweed wines fermented using muscovado sugar have significantly higher TPC than wines produced from the two other sugar types.

The reported TPC values for Cabernet Sauvignon wines varied from 1130 to $2710 \mathrm{mg} \mathrm{GAE} / \mathrm{L}$ and from 860 to $1657 \mathrm{mg} \mathrm{GAE} / \mathrm{L}$ for the Merlot wines [40]. These values are higher compared to the TPC values determined for green seaweed wines (413 to $467 \mathrm{mg}$ GAE/L) produced using muscovado sugar (considered as red wine). For white wines, the reported TPC values of grape white wines varied from $238-420 \mathrm{mg}$ GAE/L [41]. The TPC values determined for green seaweed wines fermented with refined and washed sugars (considered as white wine) ranged from $54-87 \mathrm{mg}$ GAE/L and are lower compared to the values reported for commercial grape white wines.

\subsection{Total Flavonoid Content}

The total flavonoid content (TFC) of each seaweed wine produced was determined. Total flavonoid concentration is expressed as milligram catechin equivalent per liter ( $\mathrm{mg} \mathrm{CE} / \mathrm{L}$ ). TFC values of green seaweed wines ranged from $7 \mathrm{mg} \mathrm{CE} / \mathrm{L}$ to $356 \mathrm{mg} \mathrm{CE} / \mathrm{L}$ (Figure 2) with wines fermented using muscovado sugar having the highest TFC values (294 - $356 \mathrm{mg} \mathrm{CE} / \mathrm{L})$. One green seaweed wine (GS1 - Halimeda macroloba) fermented using washed sugar has TFC value comparable to wines fermented using muscovado sugar $(311 \mathrm{mg}$ $\mathrm{CE} / \mathrm{L})$. The rest of the green seaweed wines fermented using refined and washed sugars have TFC values $<100$ $\mathrm{mg} \mathrm{CE} / \mathrm{L}$.

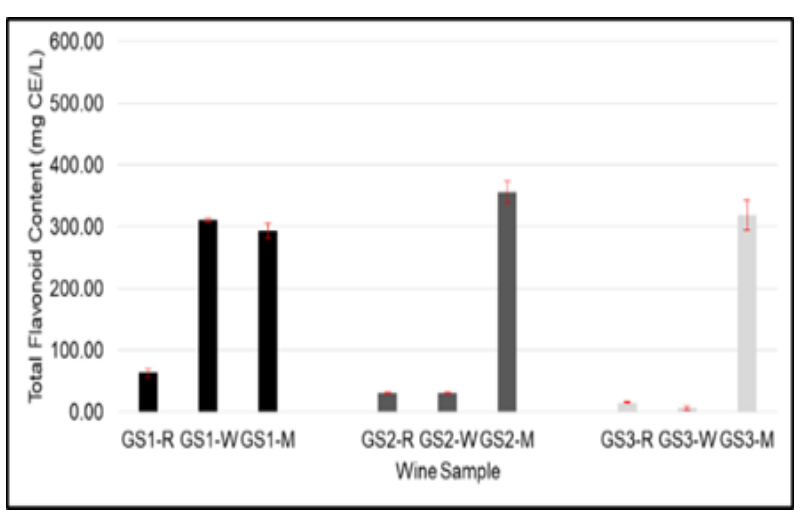

Figure 2. Total flavonoid content of wines generated from fermentation of three (3) green seaweed species. Results are expressed as mean of three (3) replicates \pm standard deviation which is indicated by an error bar.

In general, green seaweed wines fermented with muscovado sugar (considered as red wine) have the highest TFC values $(311-356 \mathrm{mg} \mathrm{CE} / \mathrm{L})$. The determined values are less compared to the TFC values reported [40] for grape wine Cabernet Sauvignon wines (860 - $2290 \mathrm{mg} \mathrm{CE} / \mathrm{L})$ and Merlot wines $(661-1,375 \mathrm{mg}$ $\mathrm{CE} / \mathrm{L})$. The TFC values of seaweed wines fermented using refined and washed sugars (considered as white wine) varied from $7-74.7 \mathrm{mg} \mathrm{CE} / \mathrm{L}(\mathrm{n}=16)$ except for one wine sample (GS1-W) having TFC values of $311 \mathrm{mg}$ $\mathrm{CE} / \mathrm{L}$. The reported TFC values for 10 Serbian white wines [41] varied from $45.30-81.32 \mathrm{mg} \mathrm{CE} / \mathrm{L}$.

\subsection{Total Antioxidant Activity}

The total antioxidant activity (TAA) of each seaweed wine produced was determined. TAA is expressed as milligram ascorbic acid equivalent per liter (mg AAE/L). The results are presented in Figure 3.

The total antioxidant activity (TAA) values of wines generated from green seaweed wines have TAA values of 97 - $558 \mathrm{mg}$ AAE/L. The kind of sugar used during fermentation has also an effect in the antioxidant activity of the produced wines (Table 4). There exists a direct relationship between TAA and TPC. According to Morina and Kongoli [19], wines rich in phenolic compounds were found to have powerful antioxidant activity. Antioxidants play a crucial role in the prevention of many diseases such as cancer, inhibiting tumor initiation and heart diseases.

Previous study [42] showed that a high total antioxidant capacity (TAC) diet could reduce the risk of hypertension incidents among women, suggesting that promoting a diet naturally rich in antioxidants might help 
prevent the development of hypertension. Villaverde et al. [42] reported that the maximal effect of TAC for hypertension could be associated with a TAC intake around $5.0 \mathrm{mmol} /$ day. Thus, drinking a glass of green seaweed wine ( $558 \mathrm{mg}$ AAE/L; $300 \mathrm{~mL}$ ) could contribute $19 \%$ of the daily TAC intake. Furthermore, several studies showed that a diet with a high antioxidant capacity will exert its protective effects against type 2 diabetes [43], non-alcoholic fatty liver disease (NAFLD) in adults [44] and increase the antioxidant capacity of serum [45].

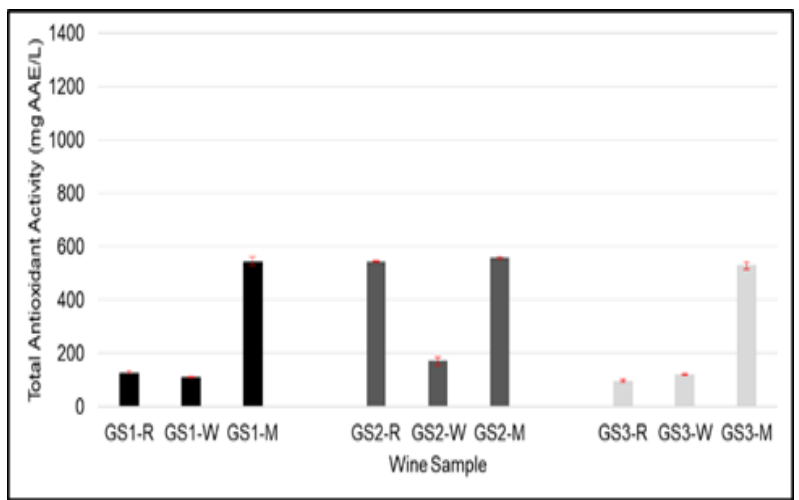

Figure 3. Total antioxidant activity of wines generated from fermentation of three (3) green seaweed species. Results are expressed as mean of three (3) replicates \pm standard deviation which is indicated by an error bar.

In general, seaweed wines produced using muscovado sugar during fermentation have higher TAA values. In this case, the type of seaweed used as a material in wine making is a significant factor to the TAA of the wine.

Table 4. Range of total antioxidant activity determined in seaweed wines produced using different kinds of sugar during fermentation.

\begin{tabular}{lc}
\hline Kind of Sugar & Total Antioxidant Activity (mg AAEL) \\
\cline { 2 - 2 } & GS Wines \\
Refined (R) & $97-544$ \\
Washed (W) & $110-171$ \\
Muscovado (M) & $528-558$
\end{tabular}

\subsection{Sensory Evaluation}

The generated seaweed wines were subjected to sensory evaluation using a 5-point rating scale. Scores of 4.3 - 5.0 was interpreted as "Liked Extremely", 3.5 - 4.2 as "Liked Very Much", 2.7 - 3.4 as "Liked Moderately", $1.9-2.6$ as "Disliked Very Much" and $1.0-1.8$ as "Disliked Extremely". The produced wines were evaluated based on color, aroma, flavor and general acceptability. Green seaweed wines fermented using muscovado sugar are liked very much while the wines fermented using washed and refined sugars are liked moderately (Table 5).

Table 5. General acceptability scores of seaweed wines produced.

\begin{tabular}{|c|c|c|c|c|c|}
\hline \multirow{3}{*}{ Wne } & \multicolumn{4}{|c|}{ Characteristics } & \multirow{3}{*}{ Remark } \\
\hline & \multirow{2}{*}{ Color } & \multirow{2}{*}{ Aroma } & \multirow{2}{*}{ Flavor } & Cereral & \\
\hline & & & & Acoeptebility & \\
\hline GS1-R & 3.7 & 3.3 & 3.3 & 3.5 & Liked Very Much \\
\hline GS1-W & 3.6 & 3.4 & 2.9 & 33 & Lked Moderately \\
\hline GS1-M & 4.0 & 3.7 & 3.3 & 3.9 & Liked Very Much \\
\hline$G S 2 \cdot R$ & 3.4 & 3.4 & 3.0 & 32 & Liked Moderateh \\
\hline GS2.W & 3.4 & 3.4 & 2.9 & 33 & Lked Moderately \\
\hline GS2-M & 3.9 & 3.8 & 3.5 & 3.8 & Liked Very Much \\
\hline GS3-R & 3.7 & 3.5 & 2.9 & 3.3 & Liked Moderately \\
\hline GS3.W & 3.7 & 3.7 & 3.3 & 3.5 & Liked Very Much \\
\hline GS3M & 4.1 & 4.0 & 3.5 & 3.9 & Liked Very Much \\
\hline
\end{tabular}

\section{CONCLUSION AND RECOMMENDATIONS}

Seaweed wines fermented using muscovado sugar have the highest total phenolic content, total flavonoid content, total antioxidant activity and liked very much. The wines produced from the studied green seaweed species have the potential to be used as functional food for the prevention of degenerative diseases caused by oxidative stress, such as hypertension, type 2 diabetes, non-alcoholic fatty liver disease (NAFLD). Also, high dietary total antioxidant capacity increases the antioxidant capacity of serum indicating absorption of the antioxidants and an improved in vivo antioxidant defense status. Assessment of the potential health benefits and safety of wines produced from green seaweeds is recommended.

\section{ACKNOWLEDGMENTS}

The researchers would like to thank the Iloilo Science and Technology University (ISAT U) for funding this study. Likewise, acknowledgement goes to Ms. Lenie Rose M. Domingo for the assistance in laboratory analyses, to Mr. Ronie D. Arbigoso, Association President of Tiabas Seaweeds Growers Association for the assistance in the collection of seaweed samples, to the people of Brgy. Tiabas, San Dionisio, Iloilo and to those who in one way or another contributed to the realization of this project.

\section{REFERENCES}

[1] Y. Kumar, A. Tarafdar, and P. Badgujar, Seaweed as a Source of Natural Antioxidants: Therapeutic 
Activity and Food Applications, Journal of Food Quality, Volume 2021, Article ID 5753391, 17 pages, 2021, https://doi.org/10.1155/2021/5753391

[2] A. Hurtado, M. Luhan, and N. Guanzon Jr., Seaweeds of Panay, (2nd ed.) Tigbauan, Iloilo, Philippines: Aquaculture Department, Southeast Asian Fisheries Development Center. 2006, http://hdl.handle.net/10862/3255,

ISBN 9789718511787

[3] BOI-Philippines, The Philippines Seaweeds Industry, Board of Investment-Philippines, Makati, 2009 ,

https://www.yumpu.com/en/document/view/11403 354/seaweeds-board-of-investments

[4] S. Khan, and S. Satam, Seaweed Mariculture: Scope and Potential in India, Aquaculture Asia, 7(4): 26-29, 2003, https://doi.org/10.1.1.512.931

[5] J. Estrada, and M. Dionisio-Sese, Sea Grapes (Caulerpa spp.) (Chlorophyta: Caulerpaceae) from Coron, Northern Palawan, Philippines with Notes on Their Harvest and Production, Tropical Natural History, 2020 , https://doi.org/10.13140/RG.2.2.30487.19365

[6] J. Estrada, M. Arboleda, and M. Dionisio- Sese, Current Status of Sea Grapes (Caulerpa Spp.) Farming and Wild Harvesting in the Philippines, Journal of Applied Phycology, 2021, https://doi.org/10.1007/s10811-021-02533-w

[7] R. Magdugo, N. Terme, M. Lang, H. Pliego-Cortés, C. Marty, A. Hurtado, G. Bedoux, and N. Bourgougnon, An Analysis of the Nutritional and Health Values of Caulerpa racemosa (Forsskål) and Ulva Fasciata (Delile)-Two Chlorophyta Collected from the Philippines, Molecules 2020, 25, 2901,

2021 , https://doi.org/10.3390/molecules25122901

[8] A. Aroyehun, S. Razak, K. Palaniveloo, T. Nagappan, N. Rahmah, G. Jin, D. Chellappan, J. Chellian, and A. Kunnath, Bioprospecting Cultivated Tropical Green Algae, Caulerpa racemosa (Forsskal) J. Agardh: A Perspective on Nutritional Properties, Antioxidative Capacity and Anti-Diabetic Potential, Foods, 2020, https://doi.org/10.3390/foods9091313

[9] F. Ruslan, D. Susanti, N. Noor, N. Aminudin and M. Taher, Bioactive Compounds, Cosmeceutical and Nutraceutical Applications of Green Seaweed Species (Chlorophyta), Squalen Bulletin of Marine and Fisheries Postharvest and Biotechnology, 2012, DOI: $10.15578 /$ squalen.514
[10] H. Hao, M. Fu, R. Yan, B. He, M. Li, Q. Liu, L. Cai, $\mathrm{X}$. Zhang, and R. Huang, Chemical Composition and Immunostimulatory Properties of Green Alga Caulerpa Racemosa Var Peltata, Food and Agricultural Immunology, 2019, DOI: 10.1080/09540105.2019.1646216

[11] S. Shah, S. Hassan, S. Bungau and Y. Si, Chemically Diverse and Biologically Active Secondary Metabolites from Marine Phylum Chlorophyta, Mar. Drugs, 2020, doi:10.3390/md18100493

[12] T. Nagappan, and C. Vairappan, (2013). Nutritional and Bioactive Properties of Three Edible Species of Green Algae, Genus Caulerpa (Caulerpaceae), Journal of Applied Phycology, 2013, DOI:10.1007/s10811-013-0147-8

[13] M. Gazali, N. Nurjanah, and N. Zamani, The Screening of Bioactive Compound of the Green Algae Halimeda Macroloba (Decaisne, 1841) as an Antioxidant Agent from Banyak Island Aceh Singkil, IOP Publishing, 2019, DOI:10.1088/17551315/348/1/012043

[14] G. Sanger, L. Rarung, B. Kaseger, J. Assa and A. Agustin, Phenolic Content and Antioxidant Activities of Five Seaweeds from North Sulawesi, Indonesia, AACL Bioflux, 2019, Volume 12, Issue $6 \quad$ ID: $\quad 1239738410$ http://www.bioflux.com.ro/docs/2019.20412050.pdf

[15] Y. Yoshie, W. Wang, Y. Hsieh and T. Suzuki, Compositional Difference of Phenolic Compounds Between Two Seaweeds, Halimeda Spp, Journal of Tokyo University of Fisheries, Vol. 88, pp. 21-24, 2002, ISSN: 0040-9014,

[16] C. Govindasamy, M. Arulpriya, R. Packiasamy, and L. Francisca, Concentration of Heavy Metals in Seagrasses Tissue of the Palk Strait, Bay of Bengal, International Journal of Environmental Sciences, Volume 2, No 1, 2011, ISSN 0976 - 4402, https://www.researchgate.net/publication/2841264 $\underline{37}$

[17] M. Puglisi, S. Engel, P. Jensen, and W. Fenical, Antimicrobial Activities of Extracts from IndoPacific Marine Plants Against Marine Pathogens and Saprophytes, Mar Bio, 2006, DOI 10.1007/s00227-006-0376-3

[18] V. Rathi, Herbal wine: A review. Journal of Nutrition and Weight Loss, Volume 3, Issue 2, 2018, DOI: $10.35248 / 2593-9793.18 .3 .113$

[19] A. Morina, and R. Kongoli, Quality Parameters of Red Wine Produced from "Kallmet" Grape Variety, Grown in Albanian Territory, Anglisticum Journal, 
(IJLLIS) 3(1): $\quad$ 64-69, 2014, https://doi.org/:10.0001/(AJ)

[20] B. Guevara, A Guidebook to Phytochemical Screening: Phytochemical and Biological, Manila City: UST Publishing House, 2005, ISBN 971-506307-1, https://www.worldcat.org/title/guidebookto-plant-screening-phytochemical-andbiological/oclc/690995543

[21] M. Sivagnanavelmurugan, Master's Thesis. Date Accessed: $\quad$ February 23, 2016., http://shodhganga.inflibnet.ac.in/bitstream/10603/3 8404/15/15 chapter\%201.pdf

[22] A. Waterhouse, Determination of Total Phenolics. In Current Protocols in Food Analytical Chemistry, Wrolstad, R.E., Ed.; John Wiley \& Sons: New York, NY, USA; Units I; pp. I1.1.1-I1.1.8, 2001, https://doi.org/10.1002/0471142913.fai0101s06

[23] K. Mitrevska, S. Grigorakis, S.Loupassaki and A. Calokerinos, Antioxidant Activity and Polyphenolic Content of North Macedonian Wines, Appl. Sci., 2020, https://doi.org/10.3390/app10062010

[24] P. Prieto, M. Pineda, and M. Aguilar, Spectrophotometric Quantitation of Antioxidant Capacity Through the Formation of a Phosphomolybdenum Complex: Specific Application to the Determination of Vitamin E, Anal Biochem.; 269:337-41, 1999, https://doi.org/10.1006/ABIO.1999.4019

[25] A. Roldan and B. Edica, Food Service and Bartending. A/R Skills Development \& Management Services, Manila. pp 179, 2001.

[26] M. Rajkovic, I. Novakovic, and A. Petrović, Determination of Titratable Acidity in White Wine, Journal of Agricultural Sciences, Belgrade. 52. 169184, 2007, https://doi.org/10.2298/JAS0702169R

[27] B. Zoecklein, K. Fugelsang, B. Gump and F. Nury, Wine Analysis and Production, Chapman \& Hall, New York, 1999, ISBN-13: 978-0834217010, ISBN-10:

0834217015 , https://www.springer.com/gp/book/978147576967 $\underline{8}$

[28] R. Boulton, V. Singleton, L. Bisson and R Kunkee, Juice and Wine Acidity, Principles and Practices of Winemaking pp 521-538, 1996, https://doi.org/10.1007/978-1-4757-6255-6_15

[29] A. Coulter, P. Godden, and L. Pretorius, Succinic Acid-How is it Formed, What is its Effect on Titratable Acidity, and What Factors Influence its Concentration in Wine? Australian and New Zealand Wine Industry Journal. 19. 16-25, 2004.
[30] S. Dhevika, and D. Balaraman, Phytochemical Profiling and Gc-Ms Analysis of Caulerpa Racemosa. Life Science Informatics Publications, 2018, https://doi.org/10.26479/2018.0405.12

[31] E. Perez-Rodriguez, J. Aguilera and F. Lopez Figueroa, Tissular localization of coumarins in the green alga Dasycladus vermicularis (Scopoli) Krasser, Journal of Experimental Botany 54(384):1093-100, 2003, https://doi.org/10.1093/jxb/erg111

[32] D. Stengel, S. Connan and Z. Popper, Algal Chemo Diversity and Bioactivity: Sources of Natural Variability and Implications for Commercial Application, Biotechnology Advances, 2011, https://doi.org/10.1016/j.biotechadv.2011.05.016

[33] T. Rajasekar, M. Shamya and J. Joseph, Screening of Phytochemical, Antioxidant Activity and AntiBacterial Activity of Marine Seaweeds, Innovare Academic Sciences Pvt Ltd., 2019, DOI: http://dx.doi.org/10.22159/ijpps.2019v11i1.29119

[34] S. AftabUddin, S. Akter, S. Hossen and M. Rahman, Antioxidant, antibacterial and cytotoxic activity of Caulerpa racemosa (Forsskål) J.Agardh and Ulva (Enteromorpha) intestinalis L, Bangladesh J. Sci. Ind. Res. 55(4), 2020, DOI: https://doi.org/10.3329/bjsir.v55i4.50959

[35] S. Rahman, S. Neaz, M. Morshed Alam, M., and J. Nur, Hypolipidemic Activity of Ethanolic Extract of Caulerpa Recemosa, BIRDEM Med J, 2019, https://doi.org/10.3329/birdem. v9i3.43080

[36] S. Shanthasubitha and S. Saravanababu, Preliminary Screening, Antioxidant and Antimicrobial Potential of Seaweeds Collected from the Coastal Area of Kanyakumari District, JPS Scientific Publications Ltd., Life Science Archives (LSA), 2016, Volume 2, Issue - 1, Page - 394 to 405, E-ISSN: 0975-8232; P-ISSN: $2320-5148$

[37] S. Roy and P. Anantharaman, Biochemical Compositions of Seaweeds Collected from Olaikuda and Vadakkadu, Rameshwaram, Southeast Coast of India, Journal of Marine Science: Research \& Development, 2017, https://doi.org/10.4172/2155$\underline{9910.1000240}$

[38] V. Rathi, Herbal Wine: A Review, Journal of Nutrition and Weight Loss, 2018, https://doi.org/10.35248/2593-9793.18.3.113

[39] R. Ramil, Phytochemical Screening and Antioxidant Properties of the Crude Extracts of Pukpuklo (Codium repens), Bal-Balulong (Hydroclathrus clathratus) and Gamet (Porphyra suborbiculata), 
2014, MMSU Science and Technology Journal. 4: 36-46, ISSN: 2012 0060,

[40] B. Jiang, and Z. Zhang, Comparison on Phenolic Compounds and Antioxidant Properties of Cabernet Sauvignon and Merlot Wines from Four Wine Grape-Growing Regions in China, Molecules, 17, 8804-882,

2012 ,

https://doi.org/10.3390/molecules17088804

[41] M. Mitić, M. Obradović, Z. Grahovac, and A. Pavlović, Antioxidant Capacities and Phenolic Levels of Different Varieties of Serbian White Wines, Molecules. $15 . \quad$ 2016-2027. 10.3390/molecules15032016, 2010, https://doi.org/10.3390/molecules15032016

[42] P. Villaverde, M. Lajous, C. MacDonald, C. Fagherazzi, F. Bonnet and M. Boutron-Ruault, High Dietary Total Antioxidant Capacity is Associated with a Reduced Risk of Hypertension in French
Women, Nutrition Journal, 2019, https://doi.org/10.1186/s12937-019-0456-0

[43] N. van der Schaft, J. Schoufour, J. Nano, J. Kiefte-de Jong, T. Muka, E. Sijbrands, M. Ikram, O. Franco and T. Voortman, Dietary Antioxidant Capacity and Risk of Type 2 Diabetes Mellitus, Prediabetes and Insulin Resistance: The Rotterdam Study, European Journal of Epidemiology 34:853-861, 2019, https://doi.org/10.1007/s10654-019-00548-9

[44] M. Sohouli, A. Sayyari, A. Lari, G. Nameni, M. Lotfi, S. Fatahi, S. Saneie, M. Găman, F. Moodi, P. Raee, S. Aghamiri, A. Rayi, A. Shahriari and V. Moodi, Journl of Human Nutrition and Diabetes, 2021, https://doi.org/10.1111/jhn.12865

[45] T. Whitehead, D. Robinson, S. Allaway, J. Syms and A. Hale, Effect of Red Wine Ingestion on the Antioxidant Capacity of Serum. Clin. Chem.; 41(1):14-6., PMID: 7813069, 1995, https://doi.org/10.1093/clinchem/41.1.32 